\title{
ABSTRAK \\ SISTEM PENGOLAHAN SAMPAH RAMAH LINGKUNGAN DI SEKOLAH KOTA MEDAN
}

Anggi Tias Pratama, Mahasiswa Pascasarjana Pendidikan Biologi, UM Malang, Jalan Semarang 5 Malang 65145, E-mail: gietyas@gmail.com

\begin{abstract}
Berdasarkan hasil observasi langsung di lapangan dan wawancara dengan dinas kebersihan kota Medan dapat dijelaskan bahwa tingkat partisipasi masyarakat dan pihak sekolah dalam menangani sampah secara mandiri masih kurang. Masyarakat masih enggan melakukan pemilahan sampah, akibatnya sampah semakin hari semakin sulit dikelolah. Mencermati fenomena tersebut maka sangatlah diperlukan model pengelolaan sampah yang baik dan tepat serta ramah lingkungan dalam upaya mewujudkan perkotaan yang bersih dan hijau. Solusi Pengolahan Sampah yang ditawarkan, yaitu menerapkan program "6M" dengan baik yaitu mengurangi, menggunakan kembali, mengganti, memisahkan, mendaur ulang, dan mengompos. Pendekatan dan teknologi pengelolaan sampah yang ditawarkan untuk mengatasi masalah sampah yang ada di sekolahsekolah adalah: teknologi composting, pengelolaan sampah mandiri, Pendauran ulang sampah, teknologi bioethanol, memperkenalkan kepada siswa tentang bagaimana cara mengenali sampah berdasarkan sifatnya, dan meminta bantuan kepada pemerintah dan perusahaan untuk menyiapkan bak sampah. Melalui cara ini diharapkan setidaknya masalah persampahan yang ada di sekolah-sekolah pada khususnya dapat dipecahkan.
\end{abstract}

kata kunci : sampah, composting, bioethanol

\section{ABSTRACT \\ TRASH PROCESSING SYSTEM ENVIRONMENTALLY FRIENDLY SCHOOL IN THE CITY OF MEDAN}

Based on the results of direct observation in the field and an interview with the cleanliness of the city of Medan can be explained that the level of public participation and the school in dealing with independently garbage still lacking. People still reluctant to garbage sorting, as a result the dump day prosessing increasingly difficult. Looking at this phenomenon and is very required waste management model of good and proper and environmentally friendly in efforts to create urban clean and green. Waste processing solutions offered, the program is to apply good $6 \mathrm{M}$ is to reduce, using back, replacing, separate, recycling, and composting. The 
technology of waste management and offered to overcome trash problem in schools, composting is technology, waste management person recyclin the trash technology bioethanol, introduce the students on how to recognize the waste in accordance with nature and ask for aid to governments and companies to prepare trash bins. Through this way hopefully, at least the issue of garbage that there are schools in particular could be resolved

Keywords: garbage, composting, bioethanol

Sampah adalah sisa kegiatan yang dilakukan oleh manusia dan proses alam yang berbentuk padat ataupun cair. Pengelolaan sampah merupakan kegiatan atau teknik yang dilakukan secara sistematis, menyeluruh, dan berkesinambungan yang meliputi pengurangan dan penanganan sampah.Sampah dapat digolongkan menjadi empat macam berdasarkan sifat fisik dan kimianya yaitu: 1) sampah ada yang mudah membusuk terdiri atas sampah organik seperti sisa sayuran, sisa daging, daun dan lain-lain; 2) sampah yang tidak mudah membusuk seperti plastik, kertas, karet, logam, sisa bahan bangunan dan lain-lain; 3) sampah yang berupa debu/abu; dan 4) sampah yang berbahaya (B-3) bagi kesehatan, seperti sampah berasal dari industri dan rumah sakit yang mengandung zat-zat kimia dan agen penyakit yang berbahaya (Berdasarkan Undang-Undang No. 18 Tahun 2008).
Masalah sampah paling besar disebabkan oleh aktivitas penduduk diwilayah perkotaan dan menurut data dinas kebersihan Kota Medan menyebutkan bahwa sekitar $60 \%$ sampah yang ada di TPA berasal dari wilayah kota, sedangkan sisanya berasal dari wilayah pinggiran kota dan dari TPA itu sendiri. Sampah yang bersumber dari kota umumnya berasal dari limbah pemukiman, industri, rumah sakit, dan tempat makan sehingga tingkat bahayanya lebih besar bila dibandingkan dengan sampah dari wilayah pedesaan. Irawati (2002) menyebutkan bahwa sebagian masyarakat di pedesaan/kota kecil kecil membuang sampah ke sungai, tetapi tidak menyebabkan permasalahan sebab jumlahnya sedikit dan didukung oleh kemampuan sungai yang mampu mengadakan self purification, jadi pengolahannya masih terbatas pada tingkat rumah tangga. 
Pertambahan sampah semakin hari semakin banyak, bahkan keberagaman dan karakteristiknya semakin beragam, hal ini disebabkan oleh pertambahan jumlah penduduk, perubahan pola konsumsi, dan gaya hidup masyarakat. Selain itu, meningkatnya daya beli masyarakat terhadap berbagai jenis bahan pokok dan hasil teknologi serta meningkatnya usaha atau kegiatan penunjang pertumbuhan ekonomi suatu daerah juga memberikan kontribusi yang besar terhadap kuantitas dan kualitas sampah yang dihasilkan. Ada banyak masalah yang ditimbulkan oleh meningkatnya volume sampah, dan hal tersebut membutuhkan solusi dan pengolahan yang efektif dan efisien. Pengelolaan sampah yang secara sembarangan dan tidak menggunakan metode yang tepat akan memberikan dampak terhadap kesehatan dan mengganggu kelestarian fungsi lingkungan baik lingkungam biotik maupun abiotik (Aryenti, 2011).

Menurut dinas kebersihan Kota Medan dan hasil observasi langsung di lapangan, didapatkan informasi bahwa selain aktivitas pemukiman, industri, rumah sakit, dan tempat makan, ternyata prilaku siswa sekolah dasar sampai menengah ikut memberikan sumbangan sampah yang besar dan menurunkan kualitas lingkungan, terutama pencemaran udara, tanah, dan pencemaran air. Masih banyak ditemukan siswa yang menempatkan sampah bukan pada tempatnya, sehingga hampir disepanjang jalan atau pekarangan sekolah, bahkan di luar sekolah bertebaran sampah dalam jumlah yang banyak serta jenis yang beragam. Kurangnya kesadaran siswa dalam menempatkan sampah pada tempatnya disebabkan oleh kurangnya penyadaran dari pihak sekolah terkait bahaya sampah dan belum adanya penyuluhan dari dinas terkait maupun dari sekolah tentang pengolahan sampah yang ramah lingkungan (Observasi dan Wawancara langsung, 2013).

Fakta yang terlihat sehari-hari menunjukkan bahwa umumnya sampah yang bersumber dari sekolah, baik dari bahan organik maupun non-organik dibuang begitu saja dalam satu bak sampah yang sama dan tercampur satusama lain dalam berbagai komposisi, bahkan siswa cenderung menempatkan sampah bukan pada tempatnya (dibuang sembarangan) dan kemudian sampah 
berpindah tempat mulai dari tempat dikarenakan kurangnya kesadaran penampungan sementara sampai ke masyarakat tentang pentinggnya menjaga tempat pembuangan akhir (TPA). kebersihan.Selain itu masyarakat dan Berdasarkan hasil observasi juga dapat pihak sekolah menganggap bahwa dijelaskan bahwa di kota Medan umunya pengelolaan sampah merupakan tanggung dan di sekolah pada khususnya, baru jawab Pemerintah Kota dalam hal ini melaksanakan pengolahan sampah dengan menerapkan program 3M yaitu mengurangi, menggunakan kembali, dan mengompos. Tetapi itupun masi tergolong rendah karena belum semua masyarakat dan sekolah dapat menerapkan pengelolaan sampah melalui program $3 \mathrm{M}$ tersebut (Ninggarwati, dkk, 2011).

Upaya pengelolaan sampah yang ramah lingkungan ini perlu dilakukan mulai dari sumber timbulnya sampah, pewadahan, pengumpulan, pemindahan, pengangkutan sampai ke tahap pengolahan akhir sampah. Upaya-upaya pemanfaatan kembali sampah yang masih bisa di daur ulang harus dilakukan sehingga dapat mengurangi sampah secara kuantitatif. Permasalahannya adalah sejauh manakah tingkat kesadaran masyarakat untuk membantu mengelola sampah yang dihasilkan. Jangankan mengelola tapi menempatkan sampah pada wadah yang telah disediakan pun sangatlah langka dilakukan hal ini

\section{PEMBAHASAN}

\section{Kondisi Sampah Di Kota Medan}

Kota Medan merupakan salah satu kota besar yang berada di Provinsi Sumatera Utara. Kota Medan terdiri dari 21 Kecamatan dan jumlah penduduknya 2.097.610 jiwa.Timbunan sampah yang di hasilakan oleh masyarakat kota Medan adalah 1,7 ton/hari dengan tingkat pelayanan $70 \%$ dari jumlah penduduk (BPS Kota Medan, 2013). Seiring peningkatan jumlah penduduk serta aktifitas masyarakatnya yang beragam maka volume timbunan dan komposisi sampah juga ikut bertambah.Penambahan jumlah timbunan sampah di TPA berpengaruh terhadap luas lahan yang harus disediakan di TPA.pihak institusi dalam hal ini Dinas Kebersihan perlu menyiapkan alternatif jangka panjang untuk menghadapi permasalahan ini, alternatif yang harus di siapkan yatu 
sistem pengelolaan sampah dari diolah secara mandiri dan menjadi sumbernya. Sementara itu, rendahnya pengetahuan, kesadaran, dan tingkat partisipasi masyarakat dalam pengelolaan sampah menjadi suatu permasalahan yang perlu mendapat perhatian dalam pengelolaan lingkungan bersih dan sehat (Dinas Kebersihan Kota Medan, 2013).

Permasalahan terpenting yang harus ditangani oleh Pemerintah Daerah Kota Medan sekarang dan akan datang adalah bagaimana mengelolah sampah yang ramah lingkungan sehingga dapat mewujudkan Kota madani yang aman dan bersih lingkungannya. Untuk mewujudkan kota bersih dan hijau, pemerintah telah mencanangkan berbagai program yang pada dasarnya bertujuan untuk mendorong dan meningkatkan kapasitas masyarakat dalam pengelolaan sampah. Program Adipura misalnya pada tahun 2012 telah mampu mengantarkan Kota Medan menjadi Kota Adipura karena semua kelurahan berhasil mendapatkan Anugerah Adipura. Walaupun telah mendapat adipura bukan berarti tidak terdapat permasalahan sampah, Apresiasi pemerintah dan masyarakat selalu dituntut untuk melakukan pengelolaan sampah sehingga pada gilirannya sampah dapat sumberdaya.

Berdasarkan hasil observasi dapat dijelaskan bahwa tingkat partisipasi masyarakat dan pihak sekolah di Kota Medan dalam menangani sampah secara mandiri masih kurang. Masyarakat masih enggan melakukan pemilahan sampah, akibatnya sampah semakin hari semakin sulit dikelolah. Mencermati fenomena tersebut maka sangatlah diperlukan model pengelolaan sampah yang baik dan tepat serta ramah lingkungan dalam upaya mewujudkan perkotaan yang bersih dan hijau di kota Medan.Pengelolaan sampah bertujuan untuk meningkatkan kesehatan masyarakat dan kualitas lingkungan serta menjadikan sampah sebagai sumberdaya. Dari sudut pandang kesehatan lingkungan, pengelolaan sampah dipandang baik jika sampah tersebut tidak menjadi media berkembang biaknya bibit penyakit serta sampah tersebut tidak menjadi medium perantara menyebarluasnya suatu penyakit. Syarat lainnya yang harus dipenuhi, yaitu tidak mencemari udara, air dan tanah, tidak menimbulkan bau (tidak mengganggu nilai estetis), tidak menimbulkan kebakaran dan yang lainnya (Aswar, 1986 dalam Nitikesari 2005). 


\section{Menurut Irawati (2002)} pengolahan sampah (urban solid waste management) di kota terbentuk oleh dua sistem pengolahan. Pertama sistem pengolahan sampah formal yakni sistem pengolahan sampah yang meliputi kegiatan-kegiatan pewadahan dan pengumpulan, pengangkutan oleh aparat pemerintah setempat melalui Dinas Kebersihan daerah. Kedua sistem pengolahan sampah informal yaitu suatu sistem pengolahan sampah yang terbentuk oleh adanya kebutuhan untuk survei dari sebagian kecil masyarakat kota di tengah transisi ekonomi desa ke kota. Pengelolaan sampah perkotaan juga memiliki faktor-faktor pendorong dan penghambat dalam upaya peningkatan partisipasi masyarakat dalam pengelolaan sampah. Menurut hasil penelitian Nitikesari (2005) faktor-faktor tersebut di antaranya adalah tingkat pendidikan, penempatan tempat sampah di dalam rumah, keberadaan pemulung, adanya aksi kebersihan, adanya peraturan tentang persampahan dan penegakan hukumnya.

\section{Timbunan Sampah di Sekolah}

Timbunan sampah yang terdapat di sekolah-sekolah tidak semuanya dapat diangkut ke TPA hal ini disebabkan kurang meratanya sarana kebersihan di Kota Medan serta kurangnya kesadaran masyarakat untuk berpartisipasi aktif dalam penanganan masalah persampahan. Jumlah sekolah di Kota Medan tahun 2013 adalah 827 Sekolah Dasar (SD), 337 Sekolah Menengah Pertama (SMP), 288 Sekolah Menengah Atas (SMA) Negeri dan Swasta (Dinas Pendidikan Kota Medan, 2013) dan jumlah ini tidak semuanya terlayani oleh Dinas Kebersihan Kota Medan

\section{Komposisi dan Karakteristik Sampah}

Dari banyaknya sekolah di Kota Medan yang menghasilkan sampah, maka dapat diketahui karakteristik sampah yang dihasilkan yaitu sebagian besar adalah limbah plastik dan kertas.

\section{Komposisi Sampah}

Komposisi sampah di beberapa sekolah yang disurvei diketahui komponen sampah baik bahan organik maupun anorganik. Untuk mengetahui komposisi sampah di sekolah-sekolah Kota Medan dapat diperoleh dengan cara meneliti langsung dari volume sampah yang ditemukan disekitar pekaranagn sekolah atau di bak sampah. Karakteristik sampah di Kota Medan berdasarkan sumbernya yaitu : berupa sisa makanan, 
kertas, plastik dan pecahan kaca, daun kering kaleng dan kulit/logam (sangat kecil) (Karindo, 2010).

\section{Pewadahan Sampah}

Pola pewadahan sampah yang digunakan adalah pola pewadahan sampah individual dan pola pewadahan sampah komunal.

1. Pola pewadahan individual : diperuntukan bagi sekolah-sekolah bertaraf unggulan/pavorit. Bentuk yang dipakai tergantung dari kemampuan pengadaannya dari pemiliknya dengan kriteria: Bentuk (Kotak, selinder, kantung, container); Sifat (Dapat diangkat, tertutup); Bahan (Logam, plastik, alternatif bahan harus bersifat kedap terhadap air, panas matahari, tahan diperlakukan kasar, mudah dibersikan.); dan Ukuran (1050 liter)

2. Pola pewadahan komunal: diperuntukan bagi sekolah bertaraf biasa atau sekolah swasta. Bentuk (Kotak); Sifat (Tidak bersatu dengan tanah, dapat diangkat, tertutup); Bahan (Logam, plastik, tahan diperlakukan kasar, mudah dibersihkan); Ukuran (510 liter).
Kondisi Pengolahan Sampah Di Sekolah

Pelaksanaan sistem pengelolaan sampah di suatu tempat tidak dapat dilaksanakan tanpa adanya koordinasi yang baik secara internal maupun eksternal, masyarakat sekolah dan pihakpihak terkait yang memberikan andil cukup besar dalam peningkatan jumlah timbunan sampah. Sistem pengelolaan yang diterapkan di sekolah-sekolah Kota Medan tidak jauh berbeda dengan sistem pengelolaan sampah yang diterapkan di beberapa sekolah yang ada di Indonesia pada umumnya, yaitu sistem pengelolaan sampah secara konvensional. Pada sistem pengelolaan konvensional ini, sampah diangkut ke TPS atau ditimbun di halaman sekolah, bahkan jika volume sampah semakin membesar dan sudah kering, maka dilakukan pembakaran. Pola pengumpulan sampah yang diterapkan di sekolah adalah pola pengumpulan secara langsung (memungut sampah yang berserakan setiap hari jumat)yang dikenal dengan nama jumat bersih, namun setelah dikumpulkan, sampah hanya dibakar atau ditimbun tanpa diolah menjadi produk tertentu yang ramah bagi lingkungan. 


\section{Pengolahan Sampah Yang Ideal}

Sesuai dengan ketentuan yang ditetapkan pada Pasal 5 UU Pengelolan Lingkungan Hidup No.23 Th.1997, bahwa masyarakat berhak atas Lingkungan hidup yang baik dan sehat. Untuk mendapatkan hak tersebut, pada Pasal 6 dinyatakan bahwa masyarakat dan pengusaha berkewajiban untuk berpartisipasi dalam memelihara kelestarian fungsi lingkungan, mencegah dan menaggulangi pencemaran dan kerusakan lingkungan. Terkait dengan ketentuan tersebut, dalam UU NO.18 Tahun 2008 secara eksplisit juga dinyatakan, bahwa setiap orang mempunyai hak dan kewajiban dalam pengelolaan sampah. Dalam hal pengelolaan sampah pasal 12 dinyatakan, setiap orang wajib mengurangi dan menangani sampah dengan cara berwawasan lingkungan. Masyarakat juga dinyatakan berhak berpartisipasi dalam proses pengambilan keputusan, pengelolaan dan pengawasan di bidang pengelolaan sampah. Tata cara partisipasi masyarakat dalam pengelolaan sampah dapat dilakukan dengan memperhatikan karakteristik dan tatanan sosial budaya daerah masing-masing. Berangkat dari ketentuan tersebut, tentu menjadi kewajiban dan hak setiap orang baik secara individu maupun secara kolektif, demikian pula kelompok masyarakat pengusaha dan komponen masyarakat lain untuk berpartisipasi dalam pengelolaan sampah dalam upaya untuk menciptakan lingkungan perkotaan dan perdesaan yang baik, bersih, dan sehat.

Menurut Irawati (2002) membahas masalah pengolahan sampah (urban solid waste management) akan mengaitkan berbagai aktor pengelola sampah yaitu pemerintah, masyarakat, pemulung/agen, dan pengusaha daur ulang. Keberhasilan pengelolaan sampah sangat ditentukan oleh kerja sama dan peran serta aktif dari masing-masing aktor pengelola tersebut. Kenyataannya menunjukkan bahwa kerja dari masing-masing aktor pengelola sampah masih dirasakan terpisah, tidak terpadu dan belum terkoordinasi dengan baik.Hasil observasi menunjukkan bahwa pengelolaan sampah di kota Medan belum dapat dilakukan oleh setiap sumber sampah dengan baik, yakni siswa masih memiliki tingkat partisipasi yang rendah terhadap pengolahan sampah. Siswa sama sekali tidak merasa bersalah dengan menggunungnya sampah di tempat-tempat penampungan sementara sampai berhari- 
hari bahkan sampai bermingu-minggu. Selain tingkat partisipasi siswa yang rendah, pemerintah kota Medan juga belum maksimal dalam kegiatan pengolahan sampah. Karena tidak maksimalnya kinerja pemerintah dalam hal ini adalah dinas kebersihan sehingga upaya pengelolaan sampah yang di sampaikan oleh dinas kebersihan juga terlihat kontradiksi dengan fakta di lapangan.

Kondisi seperti ini juga
menggambarkan bahwa masyarakat maupun pemerintah kota Medan (Dinas Kebersihan) masih melaksanakan pengolahan sampah dengan menggunakan sistem TPS-TPA. Itu pun masih belum maksimal sehingga sampah masih berada di mana-mana. Menurut Irawati (2002) Pengolahan sampah perlu diterapkan budaya "6M" yaitu: mengurangi, menggunakan kembali, mengganti, memisahkan, mendaur ulang, dan mengompos. Program "6M" merupakan upaya pengolahan sampah rumah tangga yang dapat dilakukan oleh pemukiman, pertokoan, pasar, fasilitas umum, industri, dan layanan kesehatan misalnya Rumah Sakit atau Puskesmas, dan fasilitas umum misalnya Gelanggang Olah Raga dan gedung bioskop. Untuk menyukseskan program ini maka dibutuhkan kerja sama yang baik antara aktor pengelolah sampah yakni masyarakat, pemerintah, pemulung, dan pengusaha sehingga dapat menunjang terbentuknya jaringan pengolahan sampah yang menguntungkan dan ramah lingkungan.

\section{Solusi Pengolahan Sampah yang Ditawarkan Di Sekolah}

Kondisi masalah pengolahan sampah di sekolah-sekolah yang ada di kota Medan hampir sama dengan sekolah lain, yaitu belum menerapkan program "6M" sepenuhnya. Sesuai hasil wawancara dengan beberapa guru dan kepala sekolah didapatkan informasi bahwa sampah yang ada di sekolah masih belum sepenuhnya terkelolah dengan baik. Menurut informasi dan hasil observasi langsung menunjukkan bahwa sampah yang ada di sekitar sekolah tertimbun hingga mencapai $1 \mathrm{~m}$ dan ini dibiarkan sampai berminggu-minggu sehigga menimbulkan bau busuk dan dapat mempengaruhi proses pembelajaran. Beberapa pendekatan dan teknologi pengelolaan sampah yang ditawarkan untuk mengatasi masalah sampah yang ada di sekolah-sekolah adalah: 
1. Teknologi Komposting: Pengomposan adalah salah satu cara pengolahan sampah yang merupakan proses dekomposisi dan stabilisasi bahan secara biologis dengan produk akhir yang cukup stabil untuk digunakan di lahan pertanian tanpa pengaruh yang merugikan (Haug, 1980). Penelitian yang dilakukan oleh Wahyu (2008) menemukan bahwa pengomposan dengan menggunakan metode yang lebih modern (aerasi) mampu menghasilkan kompos yang memiliki butiran lebih halus, kandungan $\mathrm{C}, \mathrm{N}$, $\mathrm{P}, \mathrm{K}$ lebih tinggi dan $\mathrm{pH}, \mathrm{C} / \mathrm{N}$ rasio, dan kandungan Colform yang lebih rendah dibandingkan dengan pengomposan secara konvensional. Pengolahan sampah dengan cara pengomposan sudah dilakukan di TPA buku deru-deru kota Medan tetapi masih secara konvensional.

2. Pengelolaan sampah mandiri: Pengolahan sampah mandiri adalah pengolahan sampah yang dilakukan oleh masyarakat/siswa di lokasi sumber sampah seperti di rumahrumah tangga/sekolah. Masyaraka/pihak sekolaht yang umumnya memiliki ruang pekarangan lebih luas memiliki peluang yang cukup besar untuk melakukan pengolahan sampah secara mandiri. Model pengelolaan sampah mandiri akan memberikan manfaat lebih baik terhadap lingkungan serta dapat mengurangi beban TPA.

3. Pendauran ulang sampah menjadi produk yang bisa digunakan untuk keperluan sehari-hari. Misalnya sampah plastic atau kardus dibuat menjadi tas, dompet, dan baju. Selain itu, sampah dari botol atau kalengkaleng bekas dapat dibuat menjadi vas bunga atau kerajinan lain yang bernilai ekonomi.

4. Teknologi bioethanol: menggunakan sampah organic cair atau padat sebagai bahan baku pembuatan bioethanol. Siswa SMA pada khususnya diberikan pelatihan tentang bagaimana pemanfaatan sampah organic cair dan padat menjadi biethanol dengan teknik fermentasi.

5. Memperkenalkan kepada siswa tentang bagaimana cara mengenali sampah berdasrkan sifatnya sehingga siswa diharapkan mampu memisahkan sampah sesuai dengan sifatnya dengan 
tujuan agar mudah didaur ulang atau lebih mudah dikelolah.

6. Meminta bantuan kepada pemerintah dan perusahaan untuk menyiapkan bak sampah kepada seluruh sekolahsekolah yang ada di kota medan

Melalui cara ini diharapkan setidaknya masalah persampahan yang ada di sekolah-sekolah pada khususnya dapat dipecahkan, disamping itu proses daur ulang limbah yang ada dapat bermanfaat untuk bahan baku sektor industri manufaktur (untuk sampah non organik), industri pertanian/agribisnis, maupun untuk penataan pertamanan dan penghijauan kota (untuk sampah organik).

\section{KESIMPULAN}

$$
\begin{aligned}
& \text { Model pengolahan sampah } \\
& \text { hendaknya melibatkan berbagai } \\
& \text { komponen pemangku kepentingan dan }
\end{aligned}
$$

hingga pengolahan sampah menjadi barang bermanfaat untuk masyarakat sekitar. Perlu adanya peningkatan motivasi segenap lapisanmasyarakat untuk peduli terhadap sampah, serta menjaga lingkungan dan seluruhkota agar selalu tertata rapi dan asri.

\section{DAFTAR PUSTAKA}

Adisasmita, Rahardjo. 2006. Membangun Desa Partisipatif. Graha Ilmu. Yogyakarta

Apriadji, Wied H. 2005. Memproses sampah. Penebar Swadaya. Jakarta Arikunto, S. 2006. Manajemen Penelitian. PT Rineka Cipta. Jakarta

Aryenti. 2011. Peningkatan Peranserta Masyarakat Melalui Gerakan Menabung Pada Bank Sampah Di Kelurahan Babakan Surabaya, Kiaracondong Bandung. Jurnal Pemukiman, Vol 6 (1), p. 40-46.

- 2011. Peningkatan Partisipasi Masyarakat Dalam Pengelolaan Sampah Dengan Cara 3R (Reduce, Reuse, Recycle) Di Lingkungan Permukiman Ditinjau Dari Segi Sosial Ekonomi Masyarakat. Jurnal Permukiman, Vol 6 (2), p. 75-83.

Bachtiar, Wardi. 2006. Sosiologi Klasik. PT. Remaja Rosdakarya. Bandung

Bungin, H. M. Burhan. 2009. Penelitian Kuantitatif. Prenada Media Group. Jakarta

Cakra. 2011. Edisi I Agustus Halaman Kota Gunungsitoli. 06 Agustus 2011.

http://suratkabarcakra.blogspot.co $\underline{\mathrm{m} / 2011 / 08 / \text { edisi-i-agustus-2011- }}$ halaman-gunung.html

Hermawan, Yoni., Roesman, O. H. 2008. Perilaku Pedagang Sayur Dalam Mengelola Lingkungan Hidup. Jurnal Bumi Lestari, Vol 8(2), p. 186-192

KJ Veeger. 1990. Realitas Sosial: Refleksi Filsafat Sosial atas Hubungan Individu-Masyarakat dalam 
Cakrawala Sejarah Sosiologi. PT Gramedia Pustaka Utama. Jakarta

Mario. 2011. Sampah Menumpuk Di Kantor Walikota Gunungsitoli. Harian Nias Bangkit. 18 Agustus $2011 . \quad$ http://www.niasbangkit.com/2011/08/sampahmenumpuk-di-kantor-wali-kotagunungsitoli/

Muchtar, Rusdi. 1994. Aspek Sosial Budaya Kebiasaan Membuang Sampah. Jurnal Lembaga Ilmu Pengetahuan Indonesia, p. 93-101

Nias, Bangkit. 2012. Martinus Lase :

Semua Permintaan Warga Telah Dipenuhi. 6 Juli 2012.

http://www.niasbangkit.com/2012/07/martinuslase-semua-permintaan-wargatelah-dipenuhi/

Pariartha Wana W. I. 2011. Sikap Pedagang Kaki Lima Terhadap Lingkungan Di Kota Denpasar. Jurnal Permukiman, Vol 2(1), p. 159-166

Riduwan. 2010. Skala Pengukuran Variabel-variabel Penelitian.

Alfabeta. Bandung

Riyanto, S., Darwin, M., Rahmawati. A. 2010. 'Korelasi antara pengetahuan dan sikap masyarakat. 25 Januari 2010. http://zaifbio.wordpress.com/2010/ 01/25/korelasi-antarapengetahuan-dan-sikapmasyarakat-terhadap-pemilahansampah-kering-dan-basah-di-desapendem-kecamatan-junrejo-kotabatu/

Ritzer, George. 2003. Sosiologi Ilmu Pengetahuan Berparadigma Ganda. PT. Raja Grafindo Persada. Jakarta

Santoso, Urip. 2009. Pengendalian Lingkungan Hidup Untuk Meraih
Adipura. Jurnal Urip Santoso, p. $1-12$

Satori, Mohamad. 2010. Pengolahan Sampah Terpadu 3R, Era Baru Manajemen Kota. LPPM. 25 Oktober 2010. http://litabamassb.info/pengelolaan-sampahterpadu-3r-era-baru-manajemensampah-kota/

Sudrajat. 2002. Mengelola Sampah. Penebar Swadaya. Jakarta

Sugiyono. 2005. Statistika untuk Penelitian. Alfabeta. Bandung

Sunarto, Kamanto. 2004. Pengantar Sosiologi (Edisi Revisi). Fakultas Ekonomi Universitas Indonesia. Jakarta

Tchobanoglous, George. Theisen, Hilary. Vigil, Samuel. 1993, Integrated Solis Waste Managemen. McGraww-Hill. New York

Widyamoko, H., dkk. 2002. Menghindari, Mengolah dan Menyingkirkan Sampah. Abdi Tandur. Jakarta 